\title{
Towards a Theological Overcoming of Anthropocentrism. The Vegetarian Choice
}

\author{
Paolo Trianni \\ (Pontificia Universitas Gregoriana; Centro Studi Cristiani Vegetariani; trianni@unigre.it) \\ ORCID: 0000-0002-8887-7346
}

\begin{abstract}
The article intends to demonstrate that a theology of vegetarianism is possible, despite some contrary evidence present in the biblical texts. Like other theologies dealing with issues not directly voiced in the Bible, it becomes possible to interpret the biblical statements in a new way, on the bases of a specific methodology. As a result, an objective comprehension will go back inductively to Sacred Scripture. The article advocates for applying this new method as well as for introducing its ethical implications into the Christian tradition. An additional supportive argument in favour of establishing the new understanding can be found in the history of the Roman Church, besides the consolidated custom of carnivorous nutrition: there has been no shortage of positions in favour of vegetarian asceticism. This stance was also represented by Thomas Aquinas. By valorizing classic Christian authors in favour of vegetarianism (starting with Jerome), the inauguration of the theology of vegetarianism becomes legitimised. Such an inauguration would reorient Christian thought toward reconsidering cosmology, ecology and topical contemporary issues such as anthropocentrism and speciesism.
\end{abstract}

Keywords: Theology of vegetarianism; Christian vegetarianism; gnosticism; theology of animals; anthropocentrism; Christian-Jewish carnivorous custom.

\section{Introduction. Prodromes of a Theology of Vegetarianism}

Theology, and specifically the Bible, are believed to be the sources of Western anthropocentrism and its speciesism ${ }^{1}$ (White 1973, 251-263; Zizioulas 2007, xi) ${ }^{2}$. For some years, however, as some recent publications have demonstrated, theological thought has begun to reflect on animal ethics (Lintner 2020) and vegetarianism (Trianni 2017). Among the significant signs that accompany such a rethinking process within Catholicism, we can also mention the ecological encyclical Laudato si' by Pope Francis and the birth of research associations such as Centro Studi Cristiani Vegetariani ${ }^{3}$.

The growing ethical orientation towards vegetarianism gave rise to a profound

1 The American historian Lynn White Jr. deserves the credit for having first clearly underlined, early in 1967, that the historical roots of the ecological crisis lie in Christian theology, especially in its Western tradition.

2 Article proofread by Stephen Dersley (ORCID:0000-0002-6765-8590)

3 Cf. https://www.centrostudicristianivegetariani.it. Worthy of note as well is the series of essays issued by Centro Studi Cristiani Vegetariani, which today has five publications with the Edizioni Messaggero (Padua). 
reinterpretation of biblical texts, to the point that today it is possible to affirm that anthropocentrism is a false problem, because, as J. Moltmann also demonstrated, anthropocentrism is due to the philosophical thought of Descartes and Bacon, rather than to Genesis 9,3 (Trianni 2017, 85-90).

Today, in short, a "theology of vegetarianism" - unthinkable until a few decades ago, even if a "theology of animals" had already been developed, especially within the Anglican world - has become possible and the vegetarian choice can no longer be based on biological-healthy, ecological, and philosophical motivations alone, but also on theological ones.

In truth, the vegetarian choice is not entirely extraneous to Christianity, although there is objective evidence that Jesus was not a vegetarian and that vegetarianism has always been the prerogative of minority groups, which were often contrasted by the official Church.

In the history of Christianity, however, there has never been a lack of theologians and authors who have recommended abstinence from meat, and a theology of vegetarianism is possible through an adequate methodological path. The Sacred Scriptures, the patristic literature, the ecclesiastical Tradition and the contemporary theological reflection offer some food for thought.

It is a fact, however, that the Roman Catholic Church has only recently begun to deal with animal ethics, ecology and vegetarianism. In this regard, Linzey's $(1998,3)$ remark that the belief that animals can be the specific subject of our respect since they were created by God, no matter how elementary it may appear to us today, did not receive much consideration over the centuries in Christian thought. The author also added that the various biblical passages related to animal creation have never been developed in systematic theological thought. This allegation, however, if not already overcome, is nowadays being overcome, as I said above.

While until a few years ago it was still an on-going, developing process, it can now be affirmed that a theology of vegetarianism has consolidated itself, although the ecclesial Tradition, the inheritor of Judaism, has never condemned carnivorous nutrition, indeed it kept and supported such a custom for centuries.

Before embarking on in-depth theological reflection, it will therefore be appropriate to draw up some general considerations on the status quaestionis. It should thus be pointed out that, although as yet there is no proper theology of vegetarianism, there are generally three different theological attitudes related to the topic of animal welfare and vegetarianism:

The first proposes, through a questionable exegesis, a nonviolent reading of the Bible, going as far as to make Jesus an apostle of vegetarianism.

The second, which is more moderate, affirms that the Sacred Scripture does not provide sufficient material to answer all the questions raised by the issue, while it holds that extending the thou shalt not kill commandment to the animal world is an addition 
that cannot be derived from the Bible itself.

The third, which is the one prevalent in Tradition, blatantly justifies the domination of man over nature and animals (Mariani 2005, 11).

With respect to these three positions, however, it should be noted that there is no real dogmatic stance officially adopted by the Catholic Church. It is not a coincidence, for instance, that the critics of vegetarianism often rely on a 1999 editorial by La Civiltà Cattolica, which is undoubtedly a prestigious magazine, but not representative of a definitive ecclesial position on the issue, and insufficient for identifying a theological dogmatic position ${ }^{4}$.

The article from La Civiltà Cattolica blatantly embraces the anthropocentric thesis of the superiority of man over nature, as well as that of the divine concession to eat everything that is mentioned in certain passages of the Bible. Essentially, it reads vegetarianism as an inessential ethical and spiritual discipline that cannot be theologically founded. On the contrary, a closer look at the Bible, at patristic literature, as well as at the theological tradition shows that the problem is more complex.

\section{From the Bible and Tradition to the Contemporary Debate: An Insight}

As for the biblical text, it should be emphasized that the Bible, and specifically Genesis, is not univocal. The various books of Sacred Scripture that touch on the question, in fact, lend themselves to various interpretations, and, in general, we can affirm that it contains passages of even opposite orientation. In particular, three passages are crucially important in the sacred text:

- Genesis 1:29

- Genesis 9:3

- Leviticus (Deuteronomy 15:23)

Without going into the specific exegesis of these passages and the consequent biblical theology, it is appropriate to underline the contradiction between the two verses of Genesis. The first biblical verse, Gn. 1:29, is in fact the triumph of vegetarianism: "I now give to you all the plants on the earth that yield seeds and all the trees whose fruit produces its seeds within it. These will be your food". In contrast, Gn. 9:3 states: "Everything that lives and moves will be your food. Just as I gave you the green grasses, I now give you everything" (Flecha 2001, 28-31). Regarding specialized studies on the philological exegesis of these two scriptural texts, we must limit ourselves here to emphasizing that it is at the very least singular that the subsequent theological tradition has always referred to the second passage and almost never to the first.

When it comes to the third text, however, Dt. 15:23 establishes the prohibition on

4 Unsigned editorial of La Civiltà Cattolica 35(70):540, as cited by Mariani $(2005,15)$. 
consuming blood. Such a prohibition can be interpreted in various ways and is to be read, however, in relation to the exclusive lordship of God over life, that is, over blood. In other words, the divine concession to eat meat, even though it is generous and unconditional, nevertheless has a basic limitation.

The Bible, however, does not provide clear and unequivocal support for a theology of vegetarianism. Likewise, patristic literature does not help, although it is extremely vast and there is no lack of evidence of support for vegetarianism among the Fathers of the Church, as some recent studies show ${ }^{5}$ (Bormolini 2000; Flecha 2001, 28-31). St. Jerome, for example, especially by virtue of his Adversus Jovinianum (Against Vigilantius), is one of the figures who mostly insisted on the need to abstain from eating meat (Criscuolo 2013, 84-93). Moreover, the episode attributed to St. Aegidius, who stood up as a deer protector, is also well-known. Within the subsequent theological history, conflicting convictions were articulated, which were even contested by severe councils, causing consequent anathemas ${ }^{6}$ (Mariani 2005, 30-31), also by virtue of Fathers' commitment, being the heirs of the vegetarian experiences of the earlier Greek philosophers (from Pythagoras to Porphyry).

St. Thomas' thought was crucial to the legitimacy of carnivorous nutrition. Linzey (1998, 2-14), for instance, imputes directly to the Dominican preacher the utilitarian attitude adopted by Christians towards animals. Aquinas - who also relied on St. Augustine - argued that it is not a sin to use a being for the purpose it is created for. Basically, according to St. Thomas $(1966,165)$, it was permissible to eat animals because they were created to serve humans, given that it is permissible to exploit plants for the use of animals, and animals for the use of man. By virtue of the success and authoritativeness recognized in St. Thomas' thought, it is possible to deduce that if the theological tradition did not develop a vegetarian sensitivity and a culture attentive to the protection of creation, this was actually due to the scholastic approach, which lasted in the Catholic context until twentieth century neo-Thomism. In other words, Thomistic teaching dominated the Western religious conception throughout the Middle Ages, whereas some theologians only began to contest it in the eighteenth century, and mainly in the Anglican context. In this respect, we owe much to John Hildrop (1682-1756), who published the essay Free Thought upon the Brute Creation in 1742; to Richard Dean, who published An Essay on the Future Life of Brutes in 1768; and to Humpry Primatt (1735-1776), who authored the volume A Dissertation on the Duty of Mercy and Sin of Cruelty to Brute Animals in 1776. It was the beginning of what would later become the so-called theology of animals. The

5 An in-depth study dedicated to the Fathers' reflection on creation can also be found in Flecha (2001).

6 To make a synthetic chronicle of the theological and spiritual debate on the topic, it could be recalled how in Ancyra, in 314 A.D., religious orders that refused to eat meat were removed. A few years later, in 324 A.D., in Gangra, the Roman Church took a stand against the Marcionites and the Manichaeans, who claimed that God was not good if he had given permission to eat meat, and also thought that those who were fed by it would not be saved. Condemnations were inflicted on those who considered meat unclean in Braga in 567 A.D. and in Aachen in 816 A.D. 
aforementioned authors' approach was mainly directed against St. Thomas, but Descartes was not excluded either, and it was precisely thanks to them that the principle, first only moral and now also legal, of "animal rights" was introduced.

Due to its cultural importance, however, one the authors who marked a turning point in the progress of animal rights and vegetarian culture was Leo Tolstoy. He, who used to love hunting in his youth, considered vegetarianism to be the first step in religious life, as the title of one of his books underlines (Tolstoy 1989, 24). The Russian narrator, in fact, maintained that the renunciation of animal nutrition is the first stage of a moral life. Furthermore, he considered vegetarianism to be an essential condition for the advent of the Kingdom of God ${ }^{7}$. Tolstoy, like his emulator Gandhi, simply extended the principle of nonviolence to the animal world and was inspired in particular by a book by Howard Williams, The Ethics of Diet, an essay of capital importance that was published in London in 1883 and of which he subsequently edited the preface to the Russian edition.

On a more purely theological level, however, two names must be mentioned: those of Albert Schweitzer and Karl Barth. Schweitzer's reflections and Barth's subsequent considerations are the basis of a theological discussion that probably also influenced Dietrich Bonhoeffer, although he did not dedicate an adequate number of pages to the theme, due perhaps to his precocious and heroic disappearance ${ }^{8}$ (Linzey 1998, 22).

Schweitzer's original theological vegetarianism, however, finds anchorage in what summarizes his main moral intuition, that is, the need to safeguard every existing being. The German theologian, missionary and physician was canoeing up an African river, when, as he saw some hippos playing in the water, he found the essential category capable of founding what he believed could express a universal ethic: "respect for life" (Schweitzer 1983, 255).

Among the few theologians who have accepted Schweitzer's ethical references we can include the one who is probably the greatest German thinker within the Lutheran sphere in the twentieth century: Karl Barth. Commenting on the Deuteronomist passage that forbids consuming the blood of animals, he noted that this prohibition is a sign that the current violence against animals does not correspond to the genuine will of God, and that the day when harm will be no longer done to animals will come. At the same time, however, Barth also noted that vegetarianism is an unsolicited anticipation of the eschatological peace ${ }^{10}$ (Mariani 2005, 27).

7 Tolstoy $(1989,25)$, commenting on how vegetarian restaurants were increasing in Germany and the United States, wrote that this progress must especially bring joy to those who seek to bring about the Kingdom of God on earth; not only because vegetarianism is in itself an important step towards this kingdom, but because it is proof that humanity's journey towards moral perfection is proceeding in a serious and authentic way.

8 Several ethical reflections by Bonhoeffer (2005) put in evidence the rights of natural life, although he does not directly speak of vegetarianism.

9 Many passages on vegetarian ethics can be found in Schweitzer, 1983, e.g., 264, 267, 270, 273, 275.

10 See also Barth, 1980, 339, for more details on his objections to Schweitzer. Linzey $(1998,7-8)$ also refers to Barth's work. 
In the wake of the discussion between these two giants of the twentieth-century theology, the Christian debate on vegetarianism and animal rights also arrived in Italy ${ }^{11}$. After the discussions in the Anglican context, and those in the Lutheran context, a debate on vegetarianism has also taken place in the Catholic world. We have progressively passed from a secular approach, such as that of Capitini or Lombardi Vallauri, to the more markedly Christian and specifically theological essays.

An important step was, for example, the translation of Andrew Linzey's work, Animal Theology ${ }^{12}$. This work, in particular, has the merit of having framed the question historically and of having systematized it, thus making subsequent studies easier, although there are critical observations that consider the theologian's essay to be weak and contradictory ${ }^{13}$. Linzey holds an imaginary conversation with various other authors within his volume. This is the case, for example, with H. Primatt, but also with R. Griffiths ${ }^{14}$. The author also refers to the well-known works of Peter Singer (1974), who in the 1970s was one of the first to strive for animal liberation.

In the Italian context, debates have arisen particularly between those who try to promote a vegetarian diet and those who oppose it. A controversial issue, for example, is the thesis that Jesus would not have consumed the paschal lamb. This belief, which still needs to be examined, was put forward and supported by Canciani (1990), a scholar who explicitly links the teaching of Jesus to the Essene movement. In his opinion, Christ would have been vegetarian in conformity with the Essenic prescription to not eat meat, and he would not have eaten the Passover lamb because the last supper would have been celebrated the day after the Jewish Passover in a building belonging to the Essenic community ${ }^{15}$ (Mariani 2005, 89).

These brief hints highlight the existence, even in Italy, of a vivid discussion on the subject, but above all they demonstrate that the theological discussion on vegetarianism actually has ancient roots. However, it clearly emerges from a brief review of biblical and patristic literature how difficult and problematic it is to lay the groundwork for a theology of vegetarianism. We need an inductive rather than deductive method, we do not need to

11 In Italy, in addition to the commitment of the Edizioni Cosmopolis publishing house, which has a series dedicated to the topic, the works by De Benedetti (1999), Canciani (1990) and Mariani $(2005,2010)$ for the Centro Gandhi Edizioni are worthy of mention.

12 Linzey's reflection on the topic already took place in the mid-seventies and his most representative volume remains Animal Theology, published in 1994. The author has also edited, together with Tom Regan, a volume that represents the first anthological manual on the subject: Animal and Christianity: A Book of Reading, published in 1989. In fact, it contains anthological excerpts from the writings by Schweitzer, Barth, Tommaso and Primatt on the vegetarian issue.

13 Mariani $(2005,37)$ claims that Linzey contradicts himself, because on the one hand he argues that the concession in Gen 9:3 is morally unacceptable, but then it would end up legitimizing - like De Benedetti and the official Catholic theology - the meat diet.

14 Within the pages of his essay, Linzey $(1998,87)$ responds to the criticisms raised by Richard Griffiths in The Human Use of Animals, and in turn disputes Griffiths' focusing too much on Genesis 9 rather than Gen 1:29.

15 In this regard, it could be added that Canciani's thesis is close to that expressed by the English historian Geoffrey Rudd in Why Kill for Food, according to which Jesus would not have eaten the lamb during the last supper because it was not a paschal dinner. 
start from the Bible, but go back to it, enhancing animal law and ethics and, in particular, philosophical reflection (Ditadi, 2010; Mannucci, 2008; Zanca, 1987).

The theology of vegetarianism requires a peculiar method called "objective understanding". The basic premise of this solution is that the Bible, even when it does not speak directly about issues that have arisen from modernity, provides nevertheless inspiring ideas with regard to which it is possible to deduce what God thinks of certain issues (Trianni 2017, 109-112).

From an ethical point of view, however, it must be posited that, even if only hypothetically the injunction to abstain from meat becomes a theological and a moral prescription accepted by the Catholic Church, it cannot become a dogma, least of all an absolute prescription or obligation. That is, vegetarianism remains a moral and spiritual option with its own particularities, in the sense that not everyone can commit to this choice, and not everyone can adopt in in their lives with intransigent radicalism. Moreover, Schweitzer $(1983,273)$ was already aware of this and recognized that no matter how seriously humans try to refrain from killing and offending, they simply cannot completely avoid it $^{16}$. Indeed, one of the most unfathomable enigmas of the cosmos is the fact that life, in order to be perpetuated, must be destroyed and extinguished by itself, with suffering. Christianity, for example, has interpreted through the doctrine of original sin the ultimate nature of such pain and evil that grips not only humans' existence, but the cosmic life in its totality.

In the eighth chapter of the Letter to the Romans, St. Paul writes about the creation

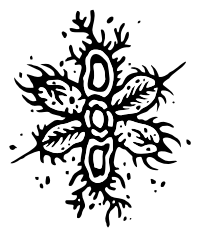
that groans in the pangs of childbirth, suggesting that the liberation from pain and violence that the cosmos suffers cannot be but an eschatological acquisition, fruit of God's grace, but also of human will and commitment. As long as humankind will reside in the terrestrial and carnal dimension, however, no absolute independence from violence will be possible. In other words, as an incarnate spirit, mortals will never be able to make themselves completely independent of the "flesh". With respect to St. Thomas' understanding of "being in the 'flesh'" or 'embodied', this entails that human actions, even involuntarily, always retain a residue of that violence that is inevitable, intrinsic and innate to existence. It cannot be soundly inferred by this, however, that the carnivorous diet must be inexorably accepted. Indeed, from this point of view, the vegetarian choice and the willingness to resist human nature, which is precisely the scandal of the ineluctable connection with brutality, is perhaps the first step, as Tolstoy believed, to transforming a fallen and violent world into a kingdom of peace.

The Church of Rome, especially today when carnivorous nutrition is no longer necessary and puts the ecological future of the planet at risk, cannot exempt itself from

16 Jain monks who wear masks so as not to kill bacteria, or Buddhist monks who do not work the land so as not to kill worms appear to be excessive forms of vegetarianism. Indeed, they are the demonstration of how worldly history seems to be hung on a mysterious guilt, or, as Teilhard de Chardin wrote, on an original incompleteness that calls for action to bring about a Kingdom of peace and love that is to come. 
pronouncing on ethical issues associated with animals. In the previous reflections we have tried to demonstrate that a theology of vegetarianism is methodologically possible, as well as doctrinally desirable. There are various reasons, in this regard, that push towards it. First of all, vegetarianism in fact has a double pastoral connotation: both within and outside Christianity. Greater attention to the animal world, for example, could recover within Catholicism all those people who have distanced themselves from the Roman Catholicism because of its age-old insensitivity to animals. From the point of view of mission, however, vegetarianism would facilitate easier dialogue and encounters with Eastern religions, which are traditionally more sympathetic to animal suffering ${ }^{17}$. From this point of view, indeed, indifferentism towards beasts appears to be a characteristic and a specific limitation of the Semitic religions alone. In addition to Judaism, whose religious culture is still linked to Old Testament sacrifices, it could be recalled that the main Islamic religious practice - the pilgrimage to Mecca - involves a bloody animal sacrifice celebrated in a sort of industrial butcher's shop. According to the Koranic faith, that is, the naive atavism of atonement through blood and animal suffering persists, although in the Islamic tradition itself, especially within the Sufi context, there are some traces of a vegetarian sensitivity ${ }^{18}$.

A second argument in support of a theology of vegetarianism certainly remains the ethical and religious one. Beyond the early patristics, where abstinence from meat was a widespread ascetic discipline, the vegetarian choice must basically be connected with the logic of the beatitudes. In other words, it falls within the logic of the new law taught in the Sermon on the Mount, in the sense that in the beatitudes there is no longer simple obedience to the Ten Commandments, but rather an invitation to perfection, holiness and excellence. From this point of view, vegetarianism, even if it cannot be an obligation, should be perceived as a duty by anyone who feels challenged to live a morally and spiritually higher life.

A third reason concerns considerations of health and ecology. In this regard, however, because it is mainly of scientific nature, I would prefer to refer the reader to all those specialized publications that are now multiplying in every part of the globe. The ecological crisis and the evident climate change have in fact increasingly forced many scientists to deal with the repercussions that intensive farming has had on pollution and hydro-geological balances.

A fourth reason is the respect for suffering. Tolstoy, whose ethical thought was

17 The French missionary and philosopher Jules Monchanin $(1985,35)$ gave an exemplary testimony on the importance of adopting a vegetarian diet from a missionary perspective in Asia. Recalling an invitation at lunch at Brahmin's home, he claims that he was accepted because he was a vegetarian and welcomed with the following words: 'The Father has respect for life'. He then claims that had he been an animal killer, he would not have been a man of God.

18 This is the case of one of the first Sufi mystics of Islam: Rabia. Greppi $(2003,40)$ reports an episode in which a Sufi went to visit Rabia, while she was playing with a deer. Asked by the visitor why the deer ran away on his arrival, Rabia replied: 'What did you eat today?'. As he answered that he had eaten meat, she commented: 'What are you surprised at then?'. Many deduce from this episode that Rabia was not only one of the few and first Sufi women, but also a vegetarian. 
focused on this issue, must be considered one of the first theologians of vegetarianism and also one of the most incisive elucidators of how much carnivorous nutrition is antithetical to eschatological aspirations. In some of his pages, for example, he narrated how the killing of a squealing pig - an event at which he had been a casual onlooker - was one of the most gruesome and disgusting scenes he had ever had to witness. Respect for animal suffering is one of the main arguments that should awaken a consciousness sensitive to animal welfare. In this regard, we could recall the words of Lanza del Vasto (1972), one of the first Christian thinkers who espoused the vegetarian cause, who discouraged people from feeding on what used to have the breath of life and lost it in pain.

\section{The Vegetarian Custom within Gnosticism}

In the context of the theology of vegetarianism, Gnosticism - and, in particular, Christian gnosis - plays an important role. This is for two conflicting reasons. The first resides in the fact that the belief in a vegetarian Christ has spread within Christian gnosis. The second reason, at the opposite extreme, derives from the observation that the prejudice that has kept Christian ethics far from adopting a vegetarian custom is also due to the battle waged by the Sanctum Officium against certain heresies linked to Gnosticism and its various historical branches.

Before considering Gnosticism, however, it should be reiterated that Greek philosophy must also be counted among its various sources. In fact, as Ditadi's (2010)

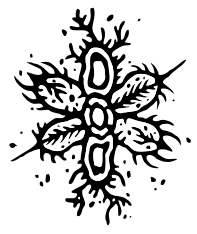
anthology demonstrates, it has paid constant attention to vegetarianism over the centuries. Theological reflection, on the other hand, has opposed philosophical speculation, especially because St. Thomas judged it legitimate to feed on animals. Moreover, fearful of the link between vegetarianism and the Gnostic heresy, theological reflection paid less and less attention to the issue. The oblivion lasted until the eighteenth century, when, especially in the Anglican world, an animal theology and a rethinking of animal law, which now has become one of the most debated themes of contemporary ethics, were developed ${ }^{19}$.

Gnosticism, however, is the religious movement that nourished that radical dualism within which vegetarianism settled down, inspired by Greek philosophers, such as Pythagoras and Plotinus's disciple, Porphyry (Sodano 2005). A history of Gnosticism and its roots goes beyond the scope of this paper ${ }^{20}$. To give a minimum of contextualization to the question, however, it could be recalled that the most recent studies have shown that its origins precede the Christian era by several centuries, going back to Babylon or Alexandria in Egypt. In the early centuries of the Christian era, the dualistic sensibility spread rapidly throughout the Greek-Christian world thanks to authors such as Valentine

19 For an examination of the current debate within Anglican animal theology (see also Massaro, 2018a, 2018b).

20 On the complex origins of Gnosticism and in relation to the ethical issues (see also Pétrement, 1984). 
and Mānī, the Iranian preacher who founded Manichaeism. The latter is also responsible for the dissemination of the Acts of Thomas, one of the New Testament apocrypha that is the basis of the Encratite Christian sect. Encratism, whose origins, as reported by Irenaeus of Lyons, date back to Satorninus of Antioch (a disciple of Simon Mago, Menander and Marcion) is based on a rigorous dualism which identifies matter with evil. The Encratites' strict continence, which included abstinence from meat, in the late Middle Ages then was reflected, through Paulicianism and Bogomilism, in the heresy of the Cathars, who were the true advocates of a Christian vegetarianism and were heavily persecuted by the Sanctum Officium.

Regarding the origins of Gnosticism and its dietary prescriptions, however, it should be noted that its roots, although difficult to document, lie in Indian thought (the dualism is structural to the Samkhya), as attested by the Acts of Thomas and even by Clement of Alexandria, who regarded Indian ascetics as the inspiring precursors of the Encratites in his Stromateis (Book I, Volume XV). This remote link with Hinduism, which would have influenced Gnostic asceticism, is certainly of great importance for a better understanding of the metaphysical path that introduced vegetarianism into Christianity. It is above all with the Cathar heresy, however, that, as mentioned above, the issue of vegetarianism became relevant. An anecdote narrates that some Cathars, in fact, were sentenced to death by the inquisitors since they had refused to kill a chicken. Against the Cathars - even if not directly against vegetarianism - the ecclesial magisterium reacted with incredible harshness, as demonstrated by the fact that the Lateran Council III promoted a Crusade against the Cathars, and that in 1208 Pope Innocent III began a severe repression in southern France, which lasted twenty years.

In general, it should be accepted that the vegetarianism of Christian Gnosticism was inspired by works such as the Clementine Homilies, which considered meat as a satanic food (Erbetta 1966). A book like I detti islamici di Gesù (The Islamic Sayings of Jesus), moreover, testifies to a Christ who was sensitive to animal welfare, as a demonstration of the circulation of Gnostic ideas linked to vegetarianism (Chialà 2009, 66). In more recent times, Szekely (1992, 10, 34-35) conjectured the idea of a vegetarian Christ not only in relation to Gnosticism, but also by virtue of a hypothetical relationship between Jesus and the Jewish sect of the Essenes.

In summary, Christian gnosis demonstrates that there has always been a Christian vegetarianism. At least two theological questions, therefore, arise spontaneously: whether the carnivorous diet makes one truly impure, and why the Western Church has harshly persecuted these religious cults. Regarding the first question, it must be reiterated that the tradition of Christianity, mindful of passages such as Mt 15:11 or Mk 7:14-23, excludes the possibility that a certain type of diet is incompatible with spiritual progress. This, for example, is the reason why even the supporters of contemporary Christian vegetarianism believe that the ultimate foundation of the vegetarian choice should not be grounded in philosophical dualism, and even less in Sacred Scripture, but in a secular ethical and 
ecologist choice.

When it comes to the question of the Roman-Catholic inquisitorial reaction, it is legitimate to hypothesize that vegetarianism was condemned because it was linked to Manichaean dualism, which ended up questioning the moral authority of Jesus. In essence, what made the ethical custom of the Catholic Church anti-vegetarian or non-vegetarian arose from the fear that the heresies linked to vegetarianism could have repercussions on Christological and Trinitarian doctrines.

\section{Conclusions}

Basically, the vegetarian choice has various foundations, not least theological. It is also possible to question the thesis that anthropocentrism emerges from a humanserving reading of biblical texts, by proposing a nonviolent interpretation of the biblical passages analysed above. The development of vegetarianism, as well as the theological publications that focus on themes concerning ecology and the spirituality of nature, allow us to claim that a development of the doctrine, as well as an evolution of the Catholic dogma, are in progress and will lead us to fully embrace in the future a Christian ethics that is committed with an increased sensitivity to animal advocacy issues and thus to overcoming, at the same time, anthropocentrism.

Translated from Italian by Sara Sgarlata

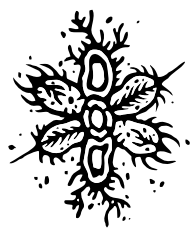

(ORCID: 0000-0001-8166-2556)

\section{References}

Barth K. 1980. Dogmatica ecclesiale. Bologna: Centro Editoriale Dehoniano.

Bellucci V. 2013. Cristo era vegetariano? Padova: Editoriale Programma.

Bonhoeffer D. 2005. Etica, Brescia: Queriniana.

Bormolini G. 2000. I vegetariani nelle tradizioni spirituali. Torino: Il Leone verde.

Canciani M. 1990. Nell'arca di Noè. Vigodarzere: Edizioni Carroccio.

Canciani M. 1955. Ultima cena dagli Esseni. Roma: Edizioni Mediterranee.

Chialà S. (Ed.). 2009. I detti islamici di Gesù. Milano: Fondazione Lorenzo Valla/Arnoldo Mondadori editore.

De Benedetti P. 1999. E l'asina disse... Magnano: Edizioni Qiqajon.

Ditadi G. (Ed.). 2010. I filosofi e gli animali, Torino: AgireOra Edizioni.

Erbetta M. (Ed.). 1966. Gli apocrifi del Nuovo Testamento. Torino: Marietti.

Flecha J. R. 2001. Il rispetto del creato. Milano: Jaca Book.

Greppi C. 2003. Rabi'a. La mistica. Milano: Jaca Book. 
Lanza del Vasto G. G. 1972. Principi e precetti del ritorno all'evidenza. Torino: Gribaudi.

Lintner M. M. 2020. Etica animale. Una prospettiva cristiana. Brescia: Queriniana.

Linzey A. \& Regan T. 1989. Animal and Christianity: A Book of Reading. London: SPCK Publishing.

Linzey A. 1998. Teologia animale. I diritti degli animali nella prospettiva teologica. Torino: Edizioni Cosmopolis.

Mannucci E. J. 2008. La cena di Pitagora. Roma: Carocci Editore.

Mariani A. 2005. Do per cibo il verde dell'erba. Il cristianesimo alla prova della condizione animale. Pisa: Centro Gandhi.

Massaro A. 2018a. Alle origini dei diritti degli animali. Milano: LED.

Massaro A. 2018b. I diritti degli animali. Una riflessione cristiana. Padova: EMP.

Monchanin J. 1985. Théologie et spiritualité missionaries. Paris: Beauchesne.

Pétrement S. 1984. Le Dieù séparé. Les origines du gnosticisme. Paris: Les Editions du Cerf.

Porfirio. 2005. Astinenza dagli animali (G. Girgenti \& A.R. Sodano, Eds.). Milano: Bompiani.

Schweitzer A. 1983. Rispetto per la vita. Milano: Edizioni di Comunità.

Singer P. 1974. "All Animals Are Equal," Philosophic Exchange 5(1):103-116.

Szekely E. B. 1992. La scoperta del Vangelo Esseno della Pace. Genova: Edizioni Naturvi.

Tolstoj L. 1989. Il primo gradino. Saggio sull'alimentazione vegetariana. Roma: Michele Manca Editore.

Tommaso D’Aquino. 1966. La Somma teologica (Volume XVII). Milano: Casa Editrice Adriano Salani.

Trianni P. 2017. Per un vegetarianesimo cristiano. Padova: EMP.

White L. 1973. "Le radici storico-culturali della nostra crisi ecologica," Il Mulino 2:251263.

Zanca G. 1987. Filosofia del vegetarianesimo. Torino: Bresci Editore. 